\title{
Maintenance management success factors for heritage building: a framework
}

\author{
Z. A. Akasah, R. M. A. Abdul \& S. N. F. Zuraidi \\ Department of Civil Engineering Technology, \\ Faculty of Civil and Environmental Engineering, \\ University Tun Hussein Onn Malaysia, Malaysia
}

\begin{abstract}
This paper attempts to establish a theoretical framework for maintenance management success factors in managing built heritage. Reviews on past literature on the subject were carried out to build the existing research works on the area and to establish critical success factors of built heritage maintenance management best practices. At the end of this paper, a new area of managing heritage building for future direction of this research was identified. A list of critical success factors for maintenance management practices for heritage building was established.
\end{abstract}

Keywords: heritage building, effective maintenance management, critical success factors.

\section{Introduction}

Heritage buildings which are not regularly maintained will become dilapidated, visually unattractive, unsafe, and endanger not only the occupants but also any nearby people. Lack of maintenance also can lead to major problems which can disturb the condition, functions, operation and performance of a building [1]. This is why maintenance should be the primary activity after the building has been listed as a heritage building. But why is maintenance often neglected and how does its importance not become the main activity in managing and protecting such a valuable and non replaceable asset?

Even though there is a bundle of literature on the importance of maintenance, the world is still faced with the unending problem after the preservation period. The need of maintenance is not only important in restoring or repairing the failed 
item, but more is required towards prevention [8]. It is the responsibility of each owner to ensure their building is always maintained regularly so that the building will continue to function in an appropriate manner [2], but the current scenario shows that only a few have done it [3]. While many of the experts have developed the initiative to approaches in tackling this matter, this paper will try to summarise the success factors for the maintenance management of heritage building.

\section{The brief picture of current Malaysian built heritage}

It is said that Malaysia has more than 35,000 old buildings, some of them which have been preserved as heritage buildings and the rest are still yet to be preserved [4]. This amount is not as high as other developing countries, but the buildings still need to be maintained regularly and continuously. Like others, there is always a lot of problems in managing the buildings and the most debated issues are the improper implementation of maintenance activity after the review period. As a developing country, Malaysia is one of the destinations chosen by tourists every year. The uniqueness and beauty of the heritage architecture is one of the products that should be seen by tourists. If we neglect the heritage buildings the image of Malaysia would be affected. In conjunction with that, the Ministry of Culture and Heritage has affirmed that his ministry will have a gradual check on all the buildings that have been proclaimed as heritage buildings throughout the country to ensure that all these buildings are well looked after and taken care of $[5]$.

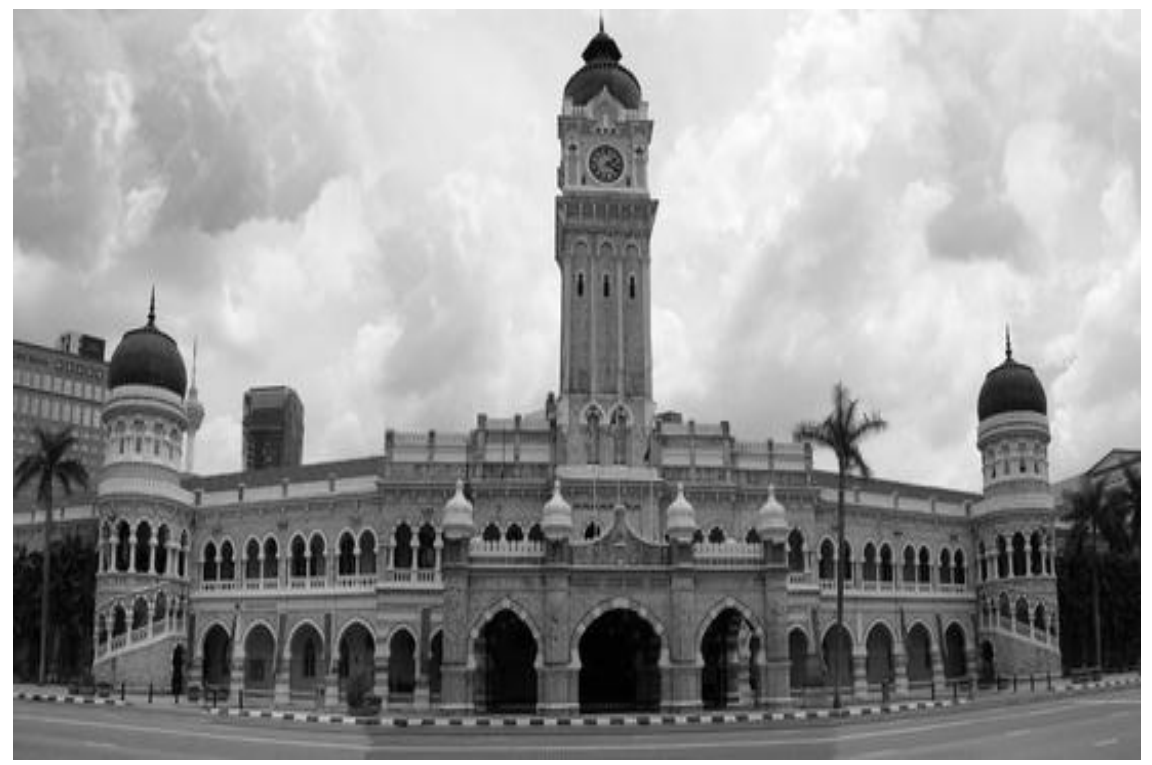

Figure 1: An example of truly beautiful Malaysian architectural heritage; Sultan Abdul Samad Building. 


\section{The importance of maintaining the heritage building}

The importance of maintaining heritage buildings gives a lot of benefits in the continuity of preservation aspect. Issues will arise if the importance of maintaining is neglected. According to 'Maintain our Heritage' [3] the importance of maintaining the heritage buildings is to increase the performance and life span of the building and it helps to convert the value of investment. Besides that, maintenance is important in maintaining the harmony and sustainability of the environment because this activity does not concern the usage of new substance and at the same time it balances up the old and new development. The same goes with the importance of preserving the building fabrication whereby many substances are difficult to achieve [8]. With the execution of maintaining, these substances are guaranteed everlasting. In reality, the importance of maintaining the heritage building not only to ensure that all the elements of the building are functioning at the same time but that it can benefit the owner too.

\section{Factors affecting maintenance success}

The following are key factors and considerations for successful implementation of a maintenance management of a heritage building:

\subsection{Funds}

Lack of funds would be considered as a huge reason for not implementing maintenance as it should be. In the absence of adequate financial support the building would not be maintained properly. Thus, the authenticity and the originality of the building will then deteriorate and at some point it will lead to major damage.

\subsection{Effective management system}

To ensure the maintenance jobs are done successfully, it is necessary to direct and control it in a systematic manner. Success results from implementing and maintaining a management system that is designed to continually improve performance while addressing the needs of all interested parties. So, a management system is about directing and controlling an organization by using a systematic approach to achieve the needs of interested parties, or in other words, the goals of the organization.

\subsection{Competence personnel}

The competent person needs to have enough practical or theoretical knowledge and experience to conduct the maintenance work. At another side, this type of personnel should have enough skills to detect defects and decide how far these will affect the safe operation of building. It is also important for the competent person to be sufficiently independent and impartial. 


\subsection{Continuous care}

On-going maintenance is the key for successful maintenance, rather than a method that is often applied of waiting and seeing what needs doing. Maintenance needs doing continuously. The care of the building should include that of the fabric, contents and its surroundings [6].

\subsection{Shared values}

Working in the different professions will give the opportunity to interact with a great many professional. Those with shared values and with whom the interrelationship has built will then become allies for the future [7].

\subsection{Training and recruitment}

Every company, every organization provides training to all levels of an organization's member of employees. Training is a function to increase the employees and managers' knowledge and skills. Training should be followed with a program based on goal setting and performance feedback.

\section{Key success factors framework for maintenance management of heritage building}

The overall practice of current maintenance of heritage buildings in Malaysia is not at a high level and much needs to be done towards best practice. The current situational has put many of the heritage buildings at risk [9]. The gap between current practice and best practice has been identified as a key for a successful maintenance management.

In order to improve the practice in future, what should be done is to make sure enough funds are put aside for maintenance expenditure. This will ensure that the maintenance jobs can run smoothly without any delays or deferment. Then, it is important for the management to be set up effectively and always be aware of every problem which can hinder the maintenance work from being done. At the same time, the management should provide knowledge and skilful personnel so that the maintenance work can be done in a proper manner.

Later, it is the responsibilities of the management and personnel to keep the maintenance work going to make sure of the continuous care of the building. This is the most important part where the team must be aware of the needs of maintenance [9]. Working in different environments can be a good advantages in sharing knowledge and values, so the team can change ideas on the new technology or any opportunity to improve their management as well as their performance. Ongoing, the team, especially the personnel, should be trained to increase their knowledge and skill. With this, it will guarantee the maintenance to be run successfully in the future.

Below is the critical success factor framework for maintenance management of heritage buildings: 


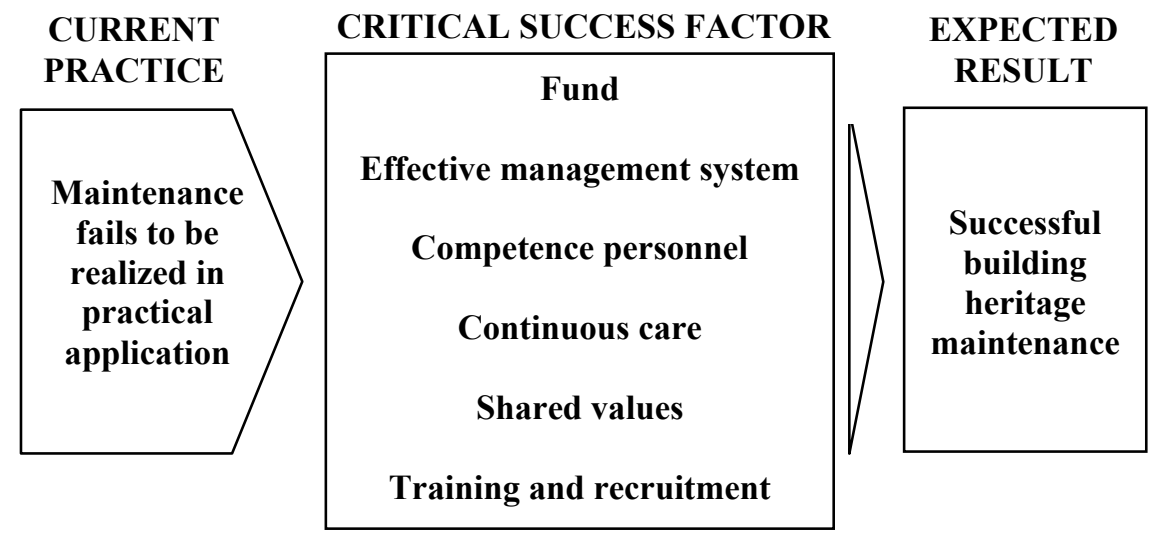

Figure 2: The critical success factor framework of building heritage maintenance management.

\section{Conclusions}

The critical success factors for maintaining heritage building has now been established as a creation of funding, effective management systems, competent personnel, continuous care, shared values and training and development. Once it has been implemented it will, like other system, require maintenance.

\section{Acknowledgements}

The authors would like to express utmost gratitude to the Faculty of Civil and Environmental Engineering of University Tun Hussein Onn Malaysia and to all colleagues for having provided support and valuable advice in carrying out the study.

\section{References}

[1] A.M.Foster \& Brit Kayan, Maintenance for historic buildings: a current perspective, Structural Survey, 27(3), pp. 210-229, 2009

[2] Dann, N. and Cantell T., Maintenance from philosophy to practice, Journal of Architectural Conservation, 11(1), pp. 42-54, 2005

[3] Maintain Our Heritage, Putting it off: How lack of Maintenance fails our Heritage, Bath, pp. $01-45,2004$

[4] Idid S.Z.A. Pemeliharaan Warisan Rupa Bandar: Panduan Mengenali Warisan Rupa Bandar Berasaskan Inventori Bangunan Warisan Malaysia, Badan Warisan Malaysia, Kuala Lumpur, 1995

[5] Mohammad Ashraf A.R., Built Heritage: Maintenance Matter, Conference on Engineering and Technology Education, World Engineering Congress 2010, Kuching, Sarawak, Malaysia, pp. 598-602, 2010 
658 Structural Repairs and Maintenance of Heritage Architecture XII

[6] International Council on Monuments and Sites, The Burra Charter, International Council and on Monuments and Sites, Paris, 1999

[7] Stephen J. Thomas, Improving Maintenance and Reliability through Cultural Change, Industrial Press Inc, New York, pp. 235-236, 2005

[8] Akasah, Z. A. and Alias, M. (2009). Application of the generic process modelling in the preservation of heritage building. Structural studies, Repairing and Maintenance XI. WIT Transaction on Built Environment, pp. 323-335 (ISSN:1743-3509).

[9] Akasah, Z. A. and Alias, M. (2009). Analysis and Development of the Generic Maintenance Management Process Modelling for the Preservation of Heritage Building. International Journal of Integrated Engineering (IJIE)Malaysia 